\title{
TO THE 90th ANNIVERSARY OF STEPAN BUTSKO
}



Stepan Stepanovich Butsko was born on June 3, 1930 in the city of Mukachevo into a family of teachers. In 1948 he graduated from Mukachevo Secondary School № 1. He continued his studies at the Faculty of Chemistry of Uzhhorod State University, from which he graduated in 1953 .

In November 1953 S.S. Butsko gained the admission to the doctoral program at the Institute of Physical Chemistry named by L.V. Pisarzhevsky of the USSR Academy of Sciences. Under the tutelage of Professor B.Ja. Dajno S.S. Butsko studied the redox properties of chlorophyll. After finishing his studies, he worked in various positions in the Department of Photochemistry and Radiation Chemistry of the same institute. In 1962 he defended his doctoral dissertation on "Dark and photochemical interactions of chlorophyll with iron salts."

S.S. Butsko started his teaching activity at Uzhhorod State University in 1963 as a senior lecturer at the Department of General and Inorganic Chemistry. From 1964 to 1966 S.S. Butsko taught chemistry at the University College of Cape Coast in the Republic of Ghana. In 1966 S.S. Butsko returns to work at Uzhhorod State University and heads the Department of General and Inorganic Chemistry. Under his leadership, the scientific direction of the department was formed, which was related to the researches in the field of coordination chemistry.
In 1968 the department launches a postgraduate program in inorganic chemistry. From 1973 to 1975 S.S. Butsko works as a senior officer of the department of scientific and technical information of the House of Soviet Science and Culture in Budapest (Hungary). After returning from abroad S.S. Butsko continues to head the Department of General and Inorganic Chemistry. From 1980 to 2008 he works at the Department of Chemical Technology and Industrial Ecology. Since 2008 S.S. Butsko has been working at the Ferenc Rakoczi II Transcarpathian Hungarian College of Higher Education. Since 2011 he has been heading the Department of Biology and Chemistry of this university, where he works up to now.

S.S. Butsko is a well-known scientist in the field of photochemistry, chemistry of complex compounds, bioinorganic chemistry and of complex processing technologies of raw materials. S.S. Butsko is the author of more than 150 scientific publications. The lines of scientific researches founded by S.S. Butsko in the field of coordination chemistry were continued by his students - DrSc., Prof. Chundak S.Yu., PhD, Assoc. Prof. Shmanko P.I., PhD, Assoc.Prof. Buzash V.M. and PhD, Assoc. Prof. Dobrjanszka L.P.

As an outstanding scientist and teacher, S.S. Butsko at different times was a member of the Scientific Council on Inorganic Chemistry of the USSR Academy of Sciences, Scientific Councils of the Academy of Sciences of Ukraine on Inorganic Chemistry, Chemical Kinetics and Structure, Surface Chemistry and Disperse Oxide Modification Technology, Scientific and Methodological Council on Chemistry of the Ministry of Higher Education of Ukraine, "Chemical Problems of Ecology" Scientific and Technical Council, and was Chairman of the Transcarpathian Regional Branch of the Ukrainian Chemical Society. The outstanding merits of S.S. Butsko's before the state were honored by the Ministry of Education and Science and the National Academy of Sciences of Ukraine.

\section{References:}

1. Shmanko P.I., Lendel V.G., Shmanko I.I. Khimiky Zakarpattia. Uzhhorod: Patent, 2003. S. 210.

2. https://www.uzhnu.edu.ua/uk/infocentre/get/6949 